\title{
Prices and the Transformation of Peasant Agriculture: the Tanzanian Case
}

\section{Frank Ellis}

\section{Introduction*}

It should be recognised at the outset that the context of socialist agriculture within which this contribution is located is itself an ambiguous matter in the Tanzanian case. This ambiguity originates in part from a shift in the emphasis of state policy from encouragement of the voluntary adoption of communal production by peasants themselves, as proposed in the original concept of ujamaa, to the compulsory nuclear villagisation of the rural population which took place in the mid-1970s. The central issue of debate has been whether the drive towards increased state intervention in the Tanzanian peasant economy, manifested also in other policies of the 1970s, can usefully be considered synonymous with the promotion of socialism in agricultural production. Opinions on this question divide between those [eg Hyden 1980] who regard the incorporation of the peasant economy into the ambit of the modernising state as a prerequisite for the transformation of production relations in agriculture, and those who view the increasing bureaucratisation of peasant-state relations as the very antithesis of a transition to participatory socialism. ${ }^{1}$

There are several notes of explanation required about the content of the discussion which follows. The first is that many of the arguments and evidence put forward represent a highly condensed summary of material set out in much greater detail in two separate papers [Ellis 1982a; forthcoming]. The second is that there exists a wide gap in the interpretation of the Tanzanian experience between those, including myself, who view the state as a significant economic entity in its own right, the behavioural characteristics and growth of which is a legitimate object of enquiry independent of the declared objectives of government leaders, and those who view the state simply as the neutral vehicle for the implementation of declared policies. ${ }^{2}$ The third

* I am grateful to Reg Green and Manfred Bienefeld for extensive comments on the $\mathrm{draft}$ of this paper. The interpretation it contains of the Tanzanian experience is of course entirely my own.

\footnotetext{
1 There are numerous potential difficulties in the definition of what might be regarded as a transition to socialist agricultural production in the Tanzanian context. The working definition implied here would require the increasing adoption, by peasants themselves, of communal production with grass-roots participation in decisionmaking (ie joint ownership and control of the means of production and participatory determination of what to produce and of the distribution of income generated from production).
}

is that the discussion focuses mainly on the period between 1970 and 1980 . It does not therefore contain any conjectural hypotheses about the likely success or failure of policy changes put into effect since 1980.

It is proposed here to examine the relationship of agricultural price policy to the unfolding of events in Tanzanian agricultural production, located in the wider context of peasant-state relationships during the 1970s. Perhaps not surprisingly, the debates concerning socialist agriculture in Tanzania tend to be distinguished more by the absence of any coherent ideas about the appropriate role of agricultural price policy than by the adoption of a logically consistent position. Leaving aside the many contributions which make no mention of agricultural prices at all, it is possible to distinguish four major propositions which appear implicitly or explicitly in the literature:

a) that agricultural prices have no active role in the promotion of socialism, since price incentives encourage individualism amongst peasants and class differentiation in the rural economy [implicit in Nyerere 1967 and also in a host of commentaries on ujamaa written in the early 1970s];

b) that peasant farmers are unresponsive to price and that therefore price levels have no significant role in achieving a greater marketed surplus from the rural economy: thus it is legitimate for the state to seek more direct methods to achieve that aim [explicit in Hyden 1980];

c) that the only significant role for agricultural prices in a transition to socialism is to transfer a financial surplus out of the rural economy in order to promote capital accumulation and industrialisation [explicit in Thomas 1974];

d) that peasant farmers are sensitive to price, with the consequence that holding down agricultural prices

\footnotetext{
${ }^{2}$ At least part of this gap appears to originate in differences in the definition of the state. The former view demands a wide definition which encompasses the rapid expansion of the state into activities, like crop marketing, previously undertaken by non-state agents [see Ellis forthcoming], while the latter view restricts the definition to the narrow area of 'public administration'. It is for this reason that the latter view is unable to comprehend the notion of peasants being squeezed to support a parasitic bureaucracy, a proposition which is readily substantiated if state agricultural marketing institutions are included within the state apparatus as a whole (see further below).
} 
creates a 'scissors crisis' for the state in which ever more coercive measures are required to extract a marketed surplus from the rural economy [explicit in Coulson 1975; Boesen 1979].

The empirical analysis of agricultural prices (to which I return in due course) would suggest that the first three of these propositions singly or in combination effectively predominated in the state approach to pricing policy in the period between 1967 and 1974, official pronouncements to the contrary notwithstanding. Between 1974 and 1980 there was a partial change of emphasis which resulted in significant real increases in food crop prices while appropriate price levels for export crops continued to be relatively neglected. In the present context interest centres on the fourth proposition. This both contradicts the preceding three as to the role of prices as an incentive to production and also contains a potential explanation of the process by which the Tanzanian state came to adopt an even more autocratic stance towards the peasantry during the $1970 \mathrm{~s}$.

In order to place these propositions about agricultural prices in perspective it is necessary to digress briefly and recap on the major initiatives taken by the Tanzanian state towards agricultural production. In what follows attention is directed first to the significance of peasant agriculture within the Tanzanian economy, secondly to the evolution of the state approach to peasant production, thirdly to the results of empirical analysis on price policy implementation, and fourthly to the lessons which can be drawn from the Tanzanian experience.

\section{Peasant Agriculture in the Tanzanian Economy}

Tanzania remains today predominantly a country of small-scale peasant agriculturalists. In the two decades since Independence was gained from Britain in 1961 the proportion of the country's population living in the rural economy has declined only gradually from 97 per cent to 85 per cent. Since the overall population growth rate was 3.3 per cent over this period, the absolute number of people living in rural areas has increased from $10 \mathrm{mn}$ to $16 \mathrm{mn}$.

Unlike some of its neighbours, Tanzania experienced only relatively minor growth of settler-based commercial agricultural during the colonial period. One implication of this is that the production of export crops such as coffee, cashew nuts, and cotton arose within peasant agriculture and did not involve the extensive alienation of land from smallholders. Another is that the production of food staples - both for subsistence consu mption and for marketed surplus - is almost wholly based on the peasant economy. Historically and contemporarily the only crops for which large-scale commercial production has been significant are sisal (now produced mainly on state plantations, and of declining importance), tea (for which there is one major foreign-owned plantation and an increasing participation by smallholders), and wheat (now produced mainly on state farms).

The foregoing is sufficient to explain the priority which has been attached to peasant agricultural production in Tanzania throughout the postIndependence period. In effect peasant agriculture constitutes the core productive base of the economy. The output performance of peasant agriculture determines both the degree of national self-sufficiency in food and, via peasant-produced export crops, the capacity of the economy to import. By extension, any development strategy not solidly based on improving the productivity and prosperity of the peasant economy would appear to invite failure at the outset. As is amply demonstrated by the current Tanzanian crisis, the pursuit of misconceived policies towards peasant agriculture renders the entire economic structure liable to imminent collapse. However, this is to jump a step ahead. The policies which have been followed first require brief elaboration.

\section{Ujamaa, Villagisation, and Beyond}

Hyden [1980] is probably correct in asserting that most of the policy initiatives of the Tanzanian state in the agricultural sphere have been consciously or unconsciously designed to draw the peasants more effectively under central state control. The conclusions he draws from this are another matter, to which I return shortly.

Ujamaa began its life as a voluntaristic concept in which peasants would be encouraged to realise the potential benefits of living and working together in villages [Nyerere 1966; 1968]. The emphasis in the earlier years after its official adoption were on communal production, self-help at the village level, and popular participation. The subsequent evolution of the policy towards compulsory villagisation has been described in detail elsewhere [Coulson 1977]. For present purposes it is sufficient to record that in late 1973 a decision was reached to move the entire rural population into nuclear villages over the following two years. At the same time the emphasis of the policy shifted away from communal production towards administrative expediency and access to services (roads, water supply, schools etc).

The contemporary administrative structure of the Tanzanian rural economy is one in which the entire peasant population is distributed between 8,299 designated villages. The majority of these are nuclear villages created or expanded during the villagisation campaign, in which between 250 and 600 (ranging in some cases to over 1,000) families are clustered 
together at one location. ${ }^{3}$ A minority, confined mainly to coffee growing areas, are simply area divisions superimposed on the pre-existing spatial distribution of peasant farmers. The minimum village size of 250 families, as also other minimum requirements for villages to achieve formal registration and thence qualify for government development projects, is enshrined in a Villages Act of $1975 .^{4}$

The village framework recognises three main forms of agricultural production: the traditional smallholding; the allocated family smallholding on the village block farm; and the communal farm. The difference between the first two lies only in the way in which access to land is determined, not in any change in the organisation of the production process. The mass relocation of previously scattered peasant families self-evidently required a minimum obligation of land distribution to those moved, and the village block farm provided a suitable vehicle to meet this obligation.

Communal production has arisen very unevenly within the village framework and is associated at least in part with the more favoured (by the state) formal status conferred on villages which can show some commitment to communal enterprise. ${ }^{5}$ A nationwide survey of 514 villages conducted in 1979 [United Republic of Tanzania, Prime Minister's Office 1980] found that 72 per cent of villages operated a communal farm, but this average conceals a wide regional variation from under 30 per cent in some regions to 100 per cent in others. Moreoever 25 per cent of those villages which stated that they had a communal farm were unable to provide any evidence as to their area under cultivation or their output. A more detailed survey of 30 villages in Ruvuma, Mbeya, and Iringa regions in southern Tanzania [Tibaijuka 1980] revealed an average communal farm size in 20 villages of 97 acres with a standard deviation of 111 acres (the size of communal farms ranged erratically between 3 and 400 acres).

\footnotetext{
${ }^{3}$ The extent to which the villagisation campaign created new settlements where none had previously existed has possibly been exaggerated in some writings on this topic. This is partly due to the neglect of the so-called 'Defence Villages' which were created in the Mtwara and Ruvuma Regions in the late $1960 \mathrm{~s}$. The striking feature of the 1974 campaign was not so much the number of the new villages created but rather the very substantial increase in the average size of villages. Thus between March 1974 and December 1975 , the number of officially recognised villages increased only from 5,008 to 6,944 while their average population grew from 511 to 1,260 .

${ }^{4}$ The full title of the 1975 village legislation is The Villages and Ujamaa Villages (Registration, Designation and Administration) Act passed in July 1975. This Act was later amended in April 1979 to allow village governments to raise revenues, to make village byelaws, and to fine village members who failed to comply with such bye-laws.

${ }^{5}$ The 1975 Village Act recognises three different levels of village status: unregistered, registered, and ujamaa. In order to qualify for the latter it is necessary to demonstrate a proven commitment to communal enterprise.
}

These and other partial surveys show that the individual family smallholding has remained after villagisation by far the majority form of agricultural production. While no precise national figure is directly available, the evidence would suggest that communal production accounts for no more than eight per cent of the total land under village crop production. ${ }^{6}$ Moreover it cannot be assumed from such evidence that communal production is on an upward trend. On the contrary, the same surveys indicate that communal enterprises have been beset with administrative and financial difficulties which may have had a widespread negative impact on peasant motivation to further their participation in such activity.

In the absence of the further adoption of communal production, the nuclear village potentially creates severely adverse conditions for the future productivity of peasant agriculture in Tanzania. This is because the distance factor from village centres demands permanent cultivation where previous peasant agronomic practices were based on bush rotations and shifting cultivation. In addition, the minimum village size of 250 families adopted during the villagisation campaign meant both that the average village size is considerably in excess of that figure (actually 347 families in 1979) and that population growth imposes increasingly severe demands on land use. Alarmed agronomists have already begun to speak of village 'deserts' created by over-intensive cultivation, deforestation (mainly for firewood), and serious soil erosion, within a walking-distance radius of each village.

The Tanzanian state has extended its direct intervention in matters affecting the peasant economy in a number of ways apart from villagisation. Some of these are of direct relevance to the way in which agricultural producer prices enter the picture, as can be noted from the following far from exhausting synopsis:

a) in 1972 a decentralisation of the state apparatus was put into effect which created a pyramidal hierarchy of administration from the central to the regional, district, ward, and village levels;

b) in 1976 the state dissolved agricultural marketing cooperatives and replaced them by parastatal crop authorities as the sole purchasing agents for crops restricted to sale through official channels;

c) between 1973 and 1976 the state changed the basis of agricultural price policy from its previous implementation at the level of sales by the

\footnotetext{
${ }^{6}$ This figure is highly approximate and may well exaggerate the significance of communal production. It is obtained simply by multiplying up a notional average communal farm size of 90 acres by the total number of villages and expressing the result as a percentage of the total estimated acreage under village crop cultivation ( $9.6 \mathrm{mn}$ acres).
} 
cooperatives to the determination centrally of uniform pan-territorial producer prices for all scheduled crops sold by the peasantry. At the same time, the coverage of agricultural price policy was extended so that by 1978 virtually the only category of crops excluded from official marketing channels, and hence legally open to commercial purchase by non-state agents, was fresh fruit and vegetables;

d) during the 1970s the state took over control of the wholesale and distribution system of consumer goods outside major towns through the creation of parastatal Regional Trading Companies (RTCs);

e) an attempt was made in 1977 to abolish private retailing in the rural economy. The incidence of severe shortages of consumer goods in villages following this decision led to its temporary suspension. However the intention was revived in 1980 when it was declared that all villages should have communal shops and that RTCs would be the sole distribution agents to such shops;

f) the legislative framework of villages was deployed by the state after 1974 to revive various colonial byelaws designed to enforce peasant compliance with state production directives. These included minimumacreage laws, fines for failure to follow cultivation practices laid down by state extension officers, fines for the uprooting or destruction of perennial tree crops, and restrictions on personal movement prior to official inspection of plots.

Most of these developments (including villagisation itself) are susceptible to at least two interpretations, bringing us back to the ambiguity with which we started. On the one hand it might be argued that they represent strenuous efforts on the part of the state to force the pace of transition to socialism via the establishment of participatory mechanisms down to the level of the individual peasant and the elimination of the market as a form of economic interaction. On the other hand, they can be interpreted as increasingly desperate attempts by an unproductive bureaucracy to wrest itself a place in the productive base of the economy via the subjugation of the peasantry. Hyden [1980] wavers between the two views, and, to the extent that he recognises some merit in the second, appears to applaud it as the only means by which a recalcitrant peasantry can be forced into the modern age.

\section{Agricultural Price Policy}

The concrete record of agricultural price policy implementation in Tanzania is highly relevant to the assessment of these different interpretations of the Tanzanian experience. This is because the conditions of existence in the typical peasant economy are quite precarious enough (and thus anyway dictate caution towards innovation) without the added imposition of persistent declining returns on external crop sales. It is certainly difficult to see how communal production could be made to appear to the peasantry as a superior alternative if the real producer prices of marketed agricultural crops were declining in precisely those years of first experimentation in communal agriculture. The observations which follow are drawn from a more detailed analysis of agricultural price and marketing policy in Tanzania [Ellis 1982a; forthcoming]. In interpreting these results it should be noted, first, that the coverage of the analysis is most peasant crops confined by Tanzanian legislation to sale through state channels; secondly, that percentage changes in weighted average price levels are expressed in real terms ie after adjustment for inflation; and thirdly, that the period of observation (1970-80) spans the complete transition from voluntary ujamaa through villagisation and post-villagisation. Where reference is made to specific categories of crops these are distinguished by their strategic role in the national economy - hence export crops are sold in external markets and are the major source of foreign exchange earnings; domestic crops are mainly for internal consumption and include staple grains (maize, rice, and wheat) and drought crops (previous subsistence or minor crops encouraged for commercial sale in the 1970 s to meet national food security objectives).

a) Agricultural producer prices declined on average by 40 per cent between 1970 and 1975 , after which they increased moderately by 7 per cent between 1975 and 1980. In 1980 prices were still 36 per cent below their 1970 level in real terms;

b) this decline was distributed unevenly between different categories of crops, such that over the whole decade export crop prices decreased by 43 per cent, staple grains prices decreased by 21 per cent, and drought crop prices rose by four per cent. For staple grains there was a sharp reversal of price policy in mid-decade so that a decline of 32 per cent between 1970 and 1974 was followed by a steep rise up to 1977 . However, the effects of this rise were rapidly eroded by an acceleration of domestic inflation from 1978 onwards;

c) trends in the composition of peasant marketed output suggest a high degree of sensitivity to changes in relative price levels between crops, especially when such shifts are sustained over several crops seasons. Taking three-year averages at the beginning and end of the decade, peasant export crop sales declined by 20 per cent, staple gains sales increased by 34 per cent and drought crop sales increased by an estimated 620 per cent (from a very small base since these crops were hardly commercialised prior to their incorporation into official marketing channels); ${ }^{7}$

\footnotetext{
${ }^{7}$ This figure obviously exaggerates the growth of drought crop sales due to lack of information on their traded quantities prior to official purchases. The basis of the figure is given in Ellis [1982a]
} 
d) the total volume of peasant output marketed through official channels stagnated during the 1970 s. $^{8}$ This was in spite of the immense non-price attention lavished on the rural sector in the form not only of the state interventions described above but also of numerous externally-funded production projects covering a wide range of smallholder crops;

e) the steep overall decline of real producer prices between 1970 and 1980 implied substantial resource transfers from peasant crop producers to the state (within which are included the parastatal crop authorities). One approach to the estimation of such transfers is to examine the comparative trends between producer prices and sales prices with a view to calculating the increase in resources absorbed in the gross marketing margin [Ellis forthcoming]. This exercise reveals that for 14 major crops marketed through official channels real producer prices declined by 31 per cent ${ }^{9}$ while real sales prices increased by 12 per cent. A consequence of these divergent treads between producer and sales prices was a phenomenal increase in the real unit gross marketing margin, estimated at 127 per cent over the observation period;

f) when these price trend relationships are converted into the financial flows with which they are associated it is found that producers received T.Shs 4.6 bn less (aggregated over the 11-year period in money terms) than they would have received if producer prices had risen in line with the sales prices of marketed crop output. Of this total amount T.Shs 2.2 bn was accounted for by increased export and sales taxes and T.Shs 2.4 bn corresponded to additional resources absorbed by the crop parastatals;

g) if the total estimated resource transfer is expressed as a percentage tax on the aggregate income which would have accrued to growers in the absence of the deterioration in their relative position, it yields an implicit average tax of 26.6 per cent at the grower level. This is additional to pre-existing levels of formal taxation on marketed agricultural production;

h) an examination of the destination of the additional resources which accrued to the crop parastatals reveals that this is one area where the notion of surplus extraction from peasants to support a parasitic bureaucracy appears rather accurate. By far the predominant cause of increased resource

\footnotetext{
${ }^{8}$ Total peasant output in $1979-80$, at 733,000 tons, was actually lower than that in 1970-71 (770,000 tons) despite the inclusion in the former figure of numerous crops which had previously not been subject to official purchases and thus do not appear in the computation of earlier marketed supply. Of course aggregate physical output is a fairly crude approximation of trends since it is influenced by shifts in composition between high bulk and low bulk commodities.

${ }^{9}$ This figure differs from that given in paragraph a) above because it is based on fewer crops (14 rather than 19), a slightly different deflator, and a different weighting procedure. These differences are fully explained in Ellis [forthcoming].
}

absorption in crop marketing was a phenomenal increase in the administrative overheads of crop parastatals, mainly consisting of their annual wage bill for permament staff. ${ }^{10}$ It is also not entirely irrelevant here that by December 1980 the crop parastatals had between them accumulated outstanding bank overdrafts T.Shs 5 bn, equivalent to nearly three times the total farm-gate value of their purchases from growers in that year.

The magnitude of the real producer price declines given above has been disputed on the grounds that the deflators used exaggerate the rise in the cost of living confronting peasants because they include items which peasants grow for their own consumption. "It is the view of the author that it is totally misleading to argue that because peasants are able, if necessary, to exist largely outside the monetary economy their cost of living should exclude items they produce for themselves. Rather, the subsistence consumption of peasants should be valued at the price at which it could otherwise have been obtained in the monetary economy since this crucially determines the extent to which peasants are able to participate in exchange and hence widen their consumption alternatives. To suggest, for example, that the cost of living confronting peasant maize growers should exclude retail food prices is to suggest quite erroneously that food price movements have no impact on their living standards. On the contrary, an increase in retail food prices compared to the producer price of maize would have the double impact both of reducing the quantity of alternative foods which could be purchased for a given quantity of maize and (if the retail maize price also moved up unfavourably) of reducing the amount of maize itself which could be purchased back in the event of shortages later in the season. Both effects have a negative impact on the material conditions of the maize grower since they curtail the scope for more diversified consumption (including a more diverse and healthier diet) and push the grower back to the level of pure subsistence.

One further point on the above results is to re-iterate that their coverage is restricted to marketed crop sales, and within that to crop sales through state marketing channels. Hence their specific focus is on price

\footnotetext{
${ }^{10}$ An indicative example is the case of a branch procurement office of the Tobacco Authority of Tanzania which employed a total of 25 permanent personnel to supervise the production and one annual collection of 13 tons of tobacco. A study of TAT management structure provoked this comment in a government report: "when one looks at the proportion of employees in each department one wonders whether the main aim to TAT is seen as the production and marketing of tobacco or as providing employment for administrators' [United Republic of Tanzania, Ministry of Agriculture, Marketing Development Bureau, 1980, Annex 11, p 34].

${ }^{11}$ These deflators are a slightly modified version of the National Consumer Price Index (NCPI) in Ellis [1982a] and the full NCPI in Ellis [forthcoming].
} 
relationships and resource flows within the institutional apparatus established by the state itself to regulate exchange with the peasant economy. The analysis does not pretend any conclusions about the extent to which evasion of formal marketing channels was important in Tanzania during the 1970s, nor about the evolution of non-marketed production, nor about the significance of marketed crops not subject to formal marketing procedures. The evidence on all such aspects is weak and highly conjectural. ${ }^{12}$

\section{Some Implications of the Tanzanian Experience}

It appears quite unequivocal that agricultural price policy has played a major negative role in the evolution of state policy towards the peasantry. This is most coherently approached via a properly dynamic interpretation of the interaction between price and production policies. The formal adoption of ujamaa in 1967 was followed soon after by a prolonged period of steeply declining agricultural producer prices fixed by the state itself. This starved the peasant economy of any economic basis for expansion at precisely the point when peasants were being exhorted to abandon their traditional agricultural practices and experiment with collective farming. It also generated the negative cycle already described: namely, the adoption by the state of a progressively more autocratic approach to the peasantry in order to try and counteract the absence of any other incentive for peasant compliance with state demands. Moreover, an additional factor was always immanent in this process: that the growth of bureaucratic institutions would itself require ever more resources to sustain their expansion and that a large proportion of such resources would need to be extracted from peasant agriculture. Hence the enormous proliferation of bureaucrats in parastatal marketing institutions was financed by the peasantry in the form of declining real prices as was also an increasing proportion of central state tax revenue.

There are two conceptually distinct but mutually reinforcing processes here: on the one hand, low agricultural prices causing lack of dynamism in the rural economy and leading to the use by the state of extra-economic coercion to force marketed surplus from the peasant economy; on the other, the proliferation of state agencies requiring more intensive surplus appropriation from the peasantry. This interpretation of Tanzanian events obviously differs from those based either in a vision of the state as the neutral vehicle for the transmission of socialist ideals, or in a view of the peasantry as an unresponsive

\footnotetext{
${ }^{12}$ Some of these weaknesses are dealt with more fully in Ellis [forthcoming].
}

(and, by default, unmotivated and obstinate) force which requires to be dragged unwillingly into a social process of someone else's devising. It is difficult, however, to see how such views can be sustained in the face of the evidence. The structure of the Tanzanian economy of itself dictated that the immense growth of the state could only be sustained by squeezing the peasants, and the unresponsiveness of the peasantry is disproved by a wealth of empirical evidence. The proposition advanced at length by Hyden [1980] that the only way forward is for the state to 'capture' the peasantry lies exposed as a sophistry.

It would be incorrect to generalise the Tanzanian experience too far. Other experiments in rural transformation have quite different roots both historically and politically, and must to a great extent be examined on their particular merits. Nevertheless there are some lessons to be learnt from Tanzania in the specific area of agricultural pricing.

First, that the level of agricultural prices and their general trend cannot simply be ignored when major organisational changes are being effected in the peasant economy. To do so is to invite a serious distortion of peasants' willingness to entertain new ideas, since the lack of motivation induced by a squeeze on peasant incomes is all too readily misinterpreted as a general inertia which in fact only exists in the minds of those in authority. Secondly, the impact of domestic inflation on the real level of returns to agricultural production cannot be ignored. At least part of the Tanzanian problem was an almost total failure to realise that money producer price increases are in themselves no guide to agricultural returns unless the prices of commodities purchased by peasants are taken into account. This problem becomés particularly acute in a state-run economy since industrial prices are typically self-adjusting (managers of state industries prices their output on a cost plus basis) while agricultural prices are not. Thirdly, it cannot be assumed that peasants (either individually or collectively) are insensitive to relative price changes between crops. The Tanzanian experience strongly indicates the very contrary. A cautious approach to changes in price relativities is indicated so that the impact of shifts can be gauged before enormous quantum jumps are effected in a particular direction. Fourthly, if it is decided for long run st rategic reasons to turn the terms of trade against agriculture, this is a process which needs very careful control. There is no point whatsoever in provoking a rapid and massive impoverishment of the rural economy if the surplus generated is simply absorbed in the recurrent expenditures of state or parastatal institutions. A controlled decline of the agricultural terms of trade linked to the specific designation of surplus for industrial investment might well have a 
role in socialist strategy, but this is certainly not the way it happened in Tanzania.

\section{Conclusion}

In extending the scope of this article to include not only price policy but the entire cycle of peasant-state relations in Tanzania, there is a risk that the sweep is too broad. However, agricultural producer price policy cannot satisfactorily be examined in isolation from the wider political and economic processes within which it is embedded. More than anything else the Tanzanian case shows that a socialist agriculture cannot be built on rhetoric and structural engineering alone. It also requires a substantive economic basis which allows the advantages of collective action to be concretely experienced by the participants in such action. Clearly this cannot be achieved by immiserising the peasant economy in the precise phase in which collective farming is first taking root.

\section{References}

Boesen, J., 1979, 'Tanzania: from ujamaa to villagisation', in B.U. Mwansasu and C. Pratt (eds), Towards Socialism in Tanzania, Tanzania Publishing House, Dar es Salaam

Coulson, A., 1975, 'Peasants and bureaucrats', Review of African Political Economy, no 3, pp 53-8
-1977, 'Agricultural policies in mainland Tanzania', Review of African Political Economy, no 10, pp 74-96

Ellis, F., 1982a, 'Agricultural price policy in Tanzania', World Development, vol 10 no 4, pp 263-83

-forthcoming, "Agricultural marketing and peasant-state transfers in Tanzania'

Hyden, G., 1980, Beyond Ujamaa: Underdevelopment and an Uncaptured Peasantry, Heinemann, London

Nyerere, J. K., 1966, Ujamaa - the basis of African socialism', in his Freedom and Unity, Oxford University Press

-1968, 'Socialism and rural development', in his Freedom and Socialism, Oxford University Press

Thomas, C. Y., 1974, Dependence and Transformation: the Economics of the Transition to Socialism, Monthly Review Press, New York

Tibaijuka, A. K., 1980, 'An economic survey of village projects in Iringa, Mbeya and Ruvuma Regions, 1979', Economic Research Bureau, University of Dar es Salaam, mimeo

United Republic of Tanzania, Ministry of Agriculture, 1980, Marketing Development Bureau, Price Policy Recommendations for the 1981-82 Agricultural Price Review, Dar es Salaam, mimeo report and annexes

United Republic of Tanzania, Prime Minister's Office, 1980, Report of Village Survey, Dodoma, April 